\title{
PHYSIOLOGICAL AND MORPHOANATOMIC RESPONSES OF Bowdichia virgilioides KUNTH. (FABACEAE) TO GLYPHOSATE
}

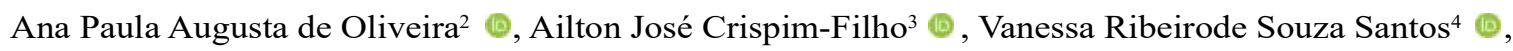
Alan Carlos Costa $^{5}$ - and Kellen Lagares Ferreira Silva ${ }^{*} \odot$

\footnotetext{
${ }^{1}$ Received on 13.10.2020 accepted for publication on 20.05.2021.

${ }^{2}$ Faculdade de Caldas Novas, Departamento de Ciências Biológicas , Caldas Novas, GO - Brasil. E-mail: <anapaulaaugustaoliveira@ gmail.com>.

${ }^{3}$ Universidade Federal de Goiás, Programa de Pós-Graduação em Genética e Melhoramento de Plantas, Goiâna, GO - Brasil. E-mail: $<$ ailtonjcf@gmail.com>.

${ }^{4}$ Universidade Federal do Tocantins, Programa de Pós-Graduação em Ciências Ambientais, Palmas, TO - Brasil. E-mail: < vanessarss@ mail.uft.edu.br> and <lagares@uft.edu.br>.

${ }^{5}$ Instituto Federal Goiano, Programa de Pós-Graduação em Ciências Agrárias-Agronomia, Rio Verde, GO - Brasil. E-mail: <alan.costa@, ifgoiano.edu.br>.

*Corresponding author.
}

\begin{abstract}
The expansion of agribusiness in Brazil is partly due to the expansion of arable areas in the Cerrado biome, which, consequently, leads to an increase in the use of herbicides, including glyphosate. Therefore, the objective of this study was to evaluate the physiological and morphoanatomic responses of Bowdichia virgilioides Kunth. (Fabaceae), when exposed to the herbicide glyphosate, under controlled greenhouse conditions. In addition, the study proposed to identify possible response patterns of the studied species and provide subsidies for the study of the species in areas affected by the drift of the herbicide. The experimental design was in randomized blocks, with seven doses of the herbicide: $25,50,100,200,400,800$, and $1200 \mathrm{~g}$ i.a ha ${ }^{-1}$ besides the control (0), with four repetitions each. Gas exchange, chlorophyll a fluorescence emission, chloroplast pigment content, membrane permeability, and visual and anatomical features were analyzed. The results showed that glyphosate is phytotoxic to B. virgilioides because, even at low doses, this herbicide was able to affect all parameters analyzed. There was also confirmation of the presence of phenolic compounds, mainly in the palisade parenchyma. The metabolic alterations presented demonstrated the sensitivity of $B$. virgilioides to glyphosate. Thus, the observed responses can serve as a tool for diagnosing the effects of glyphosate exposure on this species, present in native areas affected by the drift of this herbicide. Its indiscriminate use poses a risk to Cerrado biodiversity.
\end{abstract}

Keywords: Herbicide; Phytotoxicity; Cerrado.

\section{RESPOSTAS FISIOLÓGICAS E MORFOANATÔMICAS DE Bowdichia virgilioides KUNTH. (FABACEAE) AO GLIFOSATO}

RESUMO - A expansão do agronegócio no Brasil, se deve em parte pela ampliação das áreas agricultáveis no Cerrado, o que, consequentemente, leva a um aumento do uso de herbicidas, entre eles o glifosato. Em vista disso, objetivou-se avaliar as respostas fisiológicas e morfoanatômicos de Bowdichia virgilioides Kunth. (Fabaceae), quando expostas ao herbicida glifosato, em condições controladas de casa de vegetação. Além disso, o estudo se propôs a identificar possíveis padrões de respostas da espécie estudada, com o propósito de fornecer subsídios para o estudo da espécie, em áreas atingidas por deriva deste herbicida. $O$ delineamento experimental foi em blocos ao acaso, com sete doses do herbicida: 25, 50, 100, 200, 400, 800 e $1200 \mathrm{~g}_{\text {i.a ha-1, }}$ além d o controle (0), com quatro repetições cada. Foram analisados: trocas gasosas, emissão de fluorescência da clorofila a, conteúdo de pigmentos cloroplastídicos, permeabilidade de membrana e características visuais e anatômicas. Os resultados mostraram que o glifosato é fitotóxico para B. virgilioides, pois, mesmo em doses baixas este herbicida foi capaz de afetar todos os parâmetros analisados. Houve também a confirmação da presença de compostos fenólicos, principalmente no parênquima paliçádico. As alterações metabólicas apresentadas, comprovam a sensibilidade de B. virgilioides ao glifosato. Dessa maneira, as respostas

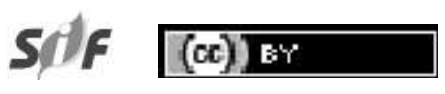

Revista Árvore 2021;45:e4528

http://dx.doi.org/10.1590/1806-908820210000028 
observadas, podem servir como ferramenta de diagnóstico dos efeitos da exposição de glifosato sobre essa espécie, presente em áreas nativas atingidas pela deriva deste herbicida. Seu uso indiscriminado é um risco à biodiversidade do Cerrado.

Palavras-Chave: Herbicida; Fitotoxicidade; Cerrado.

\section{INTRODUCTION}

Brazilian agriculture has grown at an accelerated pace, influenced by the exploration of new arable areas, associated with the modernization of machinery and implements, and the strengthening of the input sector (Belchior et al., 2014). In the last four decades, the expansion of agriculture in the Cerrado was the one that most contributed to the increase of the sector in the country, standing out in the production of soybeans, corn, cotton, sugar cane, sorghum and rice (Santana et al., 2020). However, even though it is of great importance for the Brazilian economy, agribusiness has caused several impacts to natural resources, mainly due to the exacerbated use of pesticides, which directly affect the soil, water resources and biodiversity (Gomes, 2019). In this market, herbicides, insecticides and fungicides account for $95 \%$ of the world consumption of pesticides (Pelaez et al., 2010).

Among the most widely used herbicides worldwide, glyphosate (N-phosphonomethyl glycine) stands out (Benbrook, 2016). This herbicide acts directly on the enzyme 5 enolpyruvyl-shikimate-3phosphatesynthase (EPSPS), inhibiting it, affecting the metabolic route of shikimic acid, which reduces the synthesis of essential aromatic amino acids, such as phenylalanine, tyrosine and tryptophan (Kirkwood and Mckay, 1994; Freitas-Silva et al., 2020; Santos et al., 2020). One of the most expressive characteristics of glyphosate is its rapid translocation, resulting in total destruction of plants in a short period, also having action on seeds in the soil, thus expressing its high degree of toxicity (Yamada and Castro, 2007). Thus, it is necessary to investigate the phytotoxic effects caused by glyphosate drift on native vegetation (Freitas-Silva et al., 2020).

Some research has evaluated the damage caused by glyphosate drift on native species in controlled environments, Silva et al. (2016), demonstrated that this herbicide affected all photosynthetic variables of the species Caryocar brasiliense Camb., as well as Batista et al. (2018), in Pouteriatorta. Santos et al. (2020), found that in the species Cenostigma macrophyllum Tul., gliphosate caused photosynthetic and anatomical damage, the same was described by Freitas-Silva et al. (2020), in the species Handroanthus chrysotrichus and Garcinia gardneriana, and Cruz et al. (2021), in Eugenia uniflora L. However, there is still a lack of studies on the potential damage to forest species caused by the application of herbicides (Brancalion et al., 2009). Therefore, prior knowledge of the morphoanatomical and physiological responses of native plants exposed to herbicides, acquired in controlled environments is essential, as they will serve as a tool to support the monitoring of the effects of glyphosate drift in natural vegetation.

In view of the suppression of the natural vegetation of the Cerrado caused by the expansion of agribusiness, the choice of Bowdichia virgilioides Kunth. for this study occurred because it is a native species, of wide distribution, found in the Cerrado, Caatinga, Pantanal, and Atlantic Forest, and because it is classified as a pioneer plant, tolerant to dry and poor soils, and with high potential for use in the recovery of degraded areas and reforestation, besides being highly valued economically for its ornamental, medicinal, and timber potential. The species belongs to the Fabaceae family, subfamily Papilionoideae, popularly known as sucupira-preta or paricarana, its leaves are compound, imparipinnate and alternate spiral (Lorenzi, 2008; Coêlho et al., 2019).

Therefore, this study aimed to evaluate the physiological and morphoanatomical responses of Bowdichia virgilioides Kunth (Fabaceae), when exposed to glyphosate herbicide, under controlled conditions in a greenhouse, and to identify possible patterns of responses of this exposure by the studied species, in order to provide subsidies for the study of the species in areas affected by drift of this herbicide.

\section{MATERIAL AND METHODS}

\subsection{Cultivation conditions and experimental design}

The experiment was carried out in a greenhouse, with controlled temperature and humidity. The

Revista Árvore 2021;45:e4528 
minimum temperature recorded was $23.9^{\circ} \mathrm{C}$ and the maximum $29^{\circ} \mathrm{C}$. The relative humidity of the air varied between $60.2 \%$ and $80.9 \%$. Before planting, the seeds of the species $B$. virgilioides were immersed in concentrated sulfuric acid (98\%) for 8 minutes, then washed in running water for 10 minutes to break dormancy, then placed to germinate in plastic trays containing sand. After 45 days, the seedlings were transplanted in polyethylene pots containing $3 \mathrm{~kg}$ of substrate, which consisted of a mixture of two parts of soil, type dystrophic red latosol and one of fine sand. In each pot a plant was grown, which every twenty days received a nutrient solution from Hoagland and Arnon (1950), (half strength).

Treatments were carried out 6 months after transplantation. At the time of glyphosate application, the plants were on average $20 \mathrm{~cm}$ tall, with two to four leaves on the main branch, containing three to five leaflets. The design was in randomized blocks, with seven doses of the herbicide, being: 25, 50, 100, 200, 400, 800 and $1200 \mathrm{~g}$ i.a ha ${ }^{-1}$ (grams of active ingredient per hectare) and the control (0), with four replicates for each. For application, a backpack sprayer (constant pressure maintained by $\mathrm{CO}_{2}$ ) was used, equipped with a four-point bar (XRTeeJet ${ }^{\circledR}$ ) of the $110.02 \mathrm{VP}$ series, calibrated for the application of $180 \mathrm{~L} \mathrm{ha}^{-1}$ of syrup. The spraying was done only once, in the four repetitions of each dose, at the same time.

\subsection{Physiological assessments}

For gas exchanges, six measurements were made (24, 48, 216, 244, 264 and 336 hours, after application), in fully expanded leaflets, in the median portion of the plant. In addition to gas exchange, the same area was used to assess chlorophyll a fluorescence. The photosynthetic $\left(A, \mu \mathrm{mol} \mathrm{m} \mathrm{m}^{-2} \mathrm{~s}^{-1}\right)$, transpiratory $(\mathrm{E}, \mathrm{mmol}$ $\left.\mathrm{m}^{-2} \mathrm{~s}^{-1}\right)$, stomatal conductance $\left(\mathrm{g}_{\mathrm{s}}, \mathrm{mol} \mathrm{H}_{2} \mathrm{O} \mathrm{m}^{-2} \mathrm{~s}^{-1}\right)$ and internal to external $\mathrm{CO}_{2}$ concentration $\left(\mathrm{C}_{i} / \mathrm{C}_{a}\right)$ ratios were measured using a $\mathrm{Li}$-COR portable photosynthesis meter (LI 6400 XT, LiCor, USA). For chlorophyll a fluorescence, ten measurements were performed (24, $48,72,120,144,168,216,244,264$ and 336 hours after glyphosate application), assessed using a portable modulated fluorometer (MINI-PAM, Walz, GER), with tweezers, model 2030-B (Bilger et al., 1995; Rascher et al., 2000). The potential quantum yield of photosystem II (Van Kooten and Snel, 1990) was calculated after 30 minutes of adaptation to the dark.
The evaluations of the content of chloroplast pigments and membrane permeability occurred 336 hours after the application of glyphosate. The pigments were extracted according to the methodology described by Wellburn (1994), and Moura et al. (2018). Three leaf discs were collected from each repetition, avoiding the midrib. These were incubated in glass flasks wrapped in aluminum foil, containing $5 \mathrm{ml}$ of DMSO saturated with $\mathrm{CaCO}_{3}$. Then they were placed in a water bath at a temperature of $65^{\circ} \mathrm{C}$ for 24 hours. The absorbance was determined on the UV - VIS spectrophotometer, Evolutin 60S (Thermo Fischer Scientific, USA). The wavelengths and the equations for calculating the concentrations of chlorophyll $a$, $b$ and chlorophyll $a / b$ ratio, were based on the work of Wellburn (1994). The permeability of membranes was determined using the electrolyte release rate. Fifteen $0.2 \mathrm{~cm}^{2}$ leaf discs were collected per repetition, immersed in $30 \mathrm{ml}$ of deionized water in glass flasks, left to stand for 24 hours. After this period, the free electrical conductivity and the total conductivity were measured, according to the methodology described by Vasquez-Tello et al. (1990) and Pimentel et al. (2002).

\subsection{Visual assessment of leaf symptoms}

In order to assess visual phytotoxicity, six observations were made $(24,72,120,168,240$ and 336 hours, after the application of glyphosate), by adjusting the methodology described by Novak et al. (2003). The number of leaves with visible symptoms was verified according to the percentage of affected area considering the classes: $5 \%(\mathrm{~N} 1),>5 \%$ to $25 \%$ (N2), $>25 \%$ to $50 \%(\mathrm{~N} 3),>50 \%$ at $75 \%(\mathrm{~N} 4)$ and $>75 \%$ to $100 \%$ (N5). In addition, the number of leaves without symptoms (N0) per plant was counted. The number of leaves in each class (N0 to N5) was used to calculate the leaf injury index (LII) per plant using the formula adapted by El-Khatib (2003): LII $(\%)=\frac{(\mathrm{N} 1 \times 1)(\mathrm{N} 2 \times 2)(\mathrm{N} 3 \times 3)(\mathrm{N} 4 \times 4)(\mathrm{N} 5 \times 5) \times 100}{(\mathrm{~N} 0+\mathrm{N} 1+\mathrm{N} 2+\mathrm{N} 3+\mathrm{N} 4+\mathrm{N} 5) \times 5}$ $(\mathrm{N} 0+\mathrm{N} 1+\mathrm{N} 2+\mathrm{N} 3+\mathrm{N} 4+\mathrm{N} 5) \times 5$

The severity (SI) of visible symptoms per plant was also calculated, dividing the number of leaves with symptoms by the total number of leaves of the plant, which was also expressed as a percentage. SI $(\%)=\underline{\text { Number of leaves with symptoms } \times 100}$ Total sheets

\subsection{Anatomical analyzes}

For light microscopy, four samples of each treatment were collected, 336 hours after the application

Revista Árvore 2021;45:e4528 
of the herbicide. The fully expanded leaflets were removed, and cuts were made in the median region, which were fixed in a $1 \%$ Glutaraldehyde solution, in 0.2M phosphate buffer, pH 7.2 (Karnovsky, 1965), for 24 hours, and stored in $70 \%$ alcohol. They were then dehydrated, at a time interval of 1 hour for each exchange, in ethyl and butyl series (80, 90 and 100\%, ethyl butyl (3:1), ethyl butyl (1:1), ethyl butyl (1:3) and pure butyl, remaining over night in butyl alcohol + paraffin (1:1), then they were submitted to two paraffin changes for 1 hour each. After infiltration, the samples were packed (paraffin $+8 \%$ beeswax), following the orientation of the cutting plane (transverse), with four blocks for each treatment, one for each repetition, totaling 32 blocks.

For anatomical characterization, transverse sections were made in a semi-motorized rotating microtome (RM2245, Leica, GER), 10 $\mu \mathrm{m}$ thick and adhered to the slide with Haupt adhesive (Haupt, 1930). Three slides were made for each block. The sections were deparaffinized in xylolic series, hydrated in ethyl series and stained in $1 \%$ safranin and blue for $20 \mathrm{~min}$ (Gerlach, 1984). Then, the slides were washed in distilled water and dehydrated in an ethylic series $(30 \%, 50 \%, 70 \%, 85 \%, 95 \%$ and $100 \%)$, then submitted in xylol series and mounted between slide and coverslip in balsam from Canada. Three sections were randomly selected on each slide. Images were captured by a Leica optical microscope (DM 500, Leica, GER) with a Leica camera (ICC50 HD, Leica, GER) attached. For micromorphometry, images obtained under a 40x objective, from the images, five measurements were made in each section, using the ANATI QUANTI software, version 2.0 for Windows (R) (Aguiar et al., 2007).

For the histochemical tests (phenolic compounds and tannins), sections obtained on a tabletop microtome (ROBHE/LPC, BRA), were submitted to ferric chloride and hydrochloric vanillin, at doses of (200 $\left.\mathrm{g} \mathrm{i.a} \mathrm{ha}^{-1}\right)$ and (800 g i.a ha $\left.{ }^{-1}\right)$. Cuts without any reagent were called white.

\subsection{Statistical analysis}

The data obtained for the morphometric analyzes were submitted to analysis of variance (ANOVA), and the means were compared using the Tukey test, at a 5\% significance level. Statistical analyzes were performed using the Statistica 5.0 program. The data from the physiological and phytotoxicity analyzes were subjected to analysis of variance (ANOVA) and the regression models were adjusted. Graphs and statistical analyzes were performed using SigmaPlot 10.0 software.

\section{RESULTS}

\subsection{Physiological analyzes}

The gas exchange parameters of $B$. virgilioides were affected by glyphosate (Figure 1). Decrease in the values of photosynthetic rate $(A)$ (Figure 1 and Table 1), stomatal conductance $\left(\mathrm{g}_{\mathrm{s}}\right)$ (Figure $1 \mathrm{~B}$ ) and transpiratory rate $(\mathrm{E})$ (Figure $1 \mathrm{C}$ ) and increase in the relationship between internal and external $\mathrm{CO}_{2}$ concentration $\left(\mathrm{C}_{i} / \mathrm{C}_{a}\right)$ (Figure 1D), were verified according to the increase in applied doses. Comparing the highest dose $1200 \mathrm{~g}$ i.a ha ${ }^{-1}$, with the control, $A$ showed a reduction, on average, of more than $50 \%$ in all evaluations, and in the evaluation of 216 hours after the application, this value reached $99.9 \%$. For $\mathrm{g}_{\mathrm{s}}$ these decreases were, on average, $36 \%$, presenting $58.8 \%$ in 216 hours. The reduction in $E$ followed the same pattern of $g_{s}$, about $30 \%$ on average, in all evaluations being 216 hours, with 53\% less than the control. In contrast, the $\mathrm{C}_{i} / \mathrm{C}_{a}$ ratio showed more expressive increases in the 216 hours analysis, after application, increasing by $92.2 \%$, with a dose of 1200 g i.a ha-1, compared to the control.

Changes in the fluorescence parameters of chlorophyll $a$ occurred in all doses according to the increase in its concentrations (Figure 1 and Table 1). The values of the potential quantum yield of photosystem II (Fv / Fm) (Figure 1E), were significantly reduced until the analysis of 240 hours after application. The same behavior was observed for the effective quantum yield of photosystem II ( $\Delta \mathrm{F}$ / Fm') (Figure 1F) and apparent electron transport rate (ETR) (Figure 1G). There was an increase in the non-photochemical extinction coefficient (NPQ) (Figure $1 \mathrm{H}$ ), in all evaluations, but the values were only significant in the analyzes of 24, 120 and 336 hours after application, and in the last evaluation the value with $1200 \mathrm{~g}$ i.a ha ${ }^{-1}$ dose was $36.5 \%$ higher than the control.

The results obtained for the content of chloroplast pigments (Figure 2), showed significant differences in relation to the doses applied for chlorophyll $a$

Revista Árvore 2021;45:e4528 

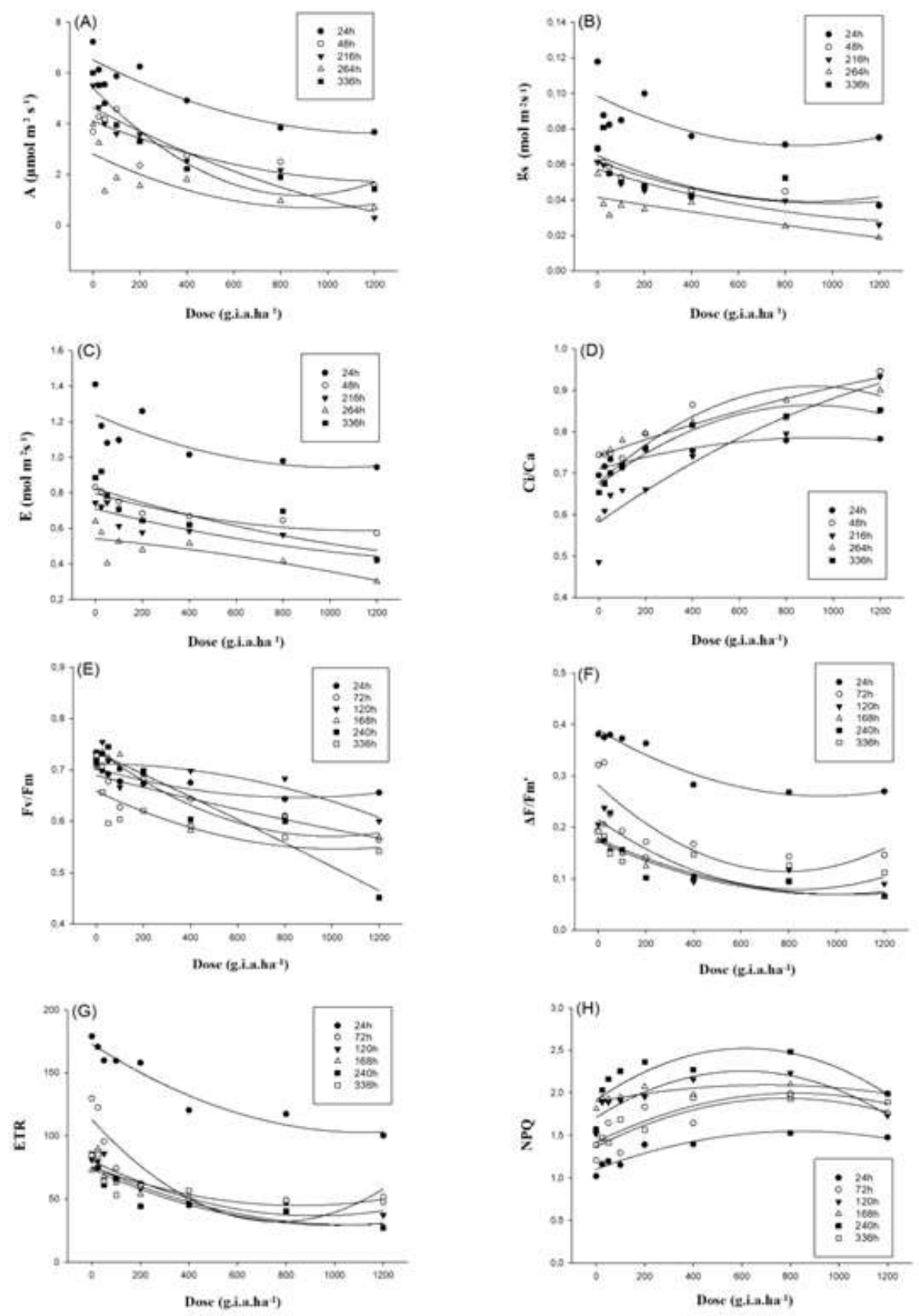

Figure 1 - A-D: Effects of glyphosate on Bowdichia virgilioides gas exchange parameters. A: photosynthetic rate (A); B: transpiration rate (E); C: stomatal conductance $\left(\mathrm{g}_{\mathrm{s}}\right) ; \mathrm{D}: \mathrm{C}_{\mathrm{i}} / \mathrm{C}_{\mathrm{a}}$ ratio. E-H: Effects of glyphosate on chlorophyll $a$ fluorescence parameters from Bowdichia virgilioides. E: potential quantum efficiency of photosystem II ( $\mathrm{Fv} / \mathrm{Fm})$; F: effective quantum yield of photosystem II $(\Delta \mathrm{F} / \mathrm{Fm}$ '); G: electron transport rate (ETR); H: non-photochemical dissipation coefficient (NPQ). For all parameters, the adjusted regression model was quadratic polynomial. Significance $* \mathrm{p}<0.05 \%$.

Figura 1 - A-D: Efeitos do glifosato nos parâmetros de trocas gasosas de Bowdichia virgilioides. A: taxa fotossintética (A); B: taxa transpiratória (E); C: condutância estomática ( $g$ ); D: razão $C / C$. E-H: Efeitos do glifosato nos parâmetros de fluorescência da clorofila a de Bowdichia virgilioides. E: rendimento quântico potencial do fotossistema II (Fv/Fm); F: rendimento quântico efetivo do fotossistema II ( $\left.\Delta F / F m^{\prime}\right) ; G$ : taxa de transporte de elétrons (ETR); H: coeficiente de dissipação não fotoquímica $(N P Q)$. Em todos os parâmetros o modelo de regressão ajustado foi polinomial quadrático. Significância * $p<0,05 \%$.

Revista Árvore 2021;45:e4528 
Table 1 - Adjusted regression equations for gas exchange and chlorophyll $a$ fluorescence in $B$. virgilioides plants subjected to different concentrations of glyphosate. They refer to Figure 1.

Tabela 1 - Equações de regressão ajustadas para trocas gasosas e fluorescência da clorofila a, em plantas de B. virgilioides submetidas a diferentes concentrações de glifosato. Referem-se à Figura 1.

\begin{tabular}{|c|c|c|c|}
\hline Features & Unit & Adjusted equations & $\mathrm{R}^{2}$ \\
\hline $\bar{A}$ & 24 hours after application & $y=6,5181-0,0047 x+2 E-06 x^{2}$ & $0,85^{*}$ \\
\hline$A$ & 48 hours after application & $y=4,1068-0,0037 x+1 E-06 x^{2}$ & $0,72^{*}$ \\
\hline$A$ & 216 hours after application & $y=4,6425-0,0049 x+1 E-06 x^{2}$ & $0,90^{*}$ \\
\hline$A$ & 264 hours after application & $y=2,8092-0,0045 x+2 E-06 x^{2}$ & $0,56^{\text {ns }}$ \\
\hline$A$ & 336 hours after application & $y=5,4184-0,0096 x+5 E-06 x^{2}$ & $0,92^{*}$ \\
\hline$g_{s}$ & 24 hours after application & $y=0,0985-7 E-05 x+4 E-08 x^{2}$ & $0,49^{\text {ns }}$ \\
\hline$g_{s}$ & 48 hours after application & $y=0,00574-4 E-05 x+1 E-08 x^{2}$ & $0,82^{*}$ \\
\hline$g_{s}$ & 216 hours after application & $y=0,0493-2 E-05 x+2 E-10 x^{2}$ & $0,88^{*}$ \\
\hline$g_{s}$ & 264 hours after application & $y=0,0414+2 E-05 x-2 E-09 x^{2}$ & $0,61^{\mathrm{ns}}$ \\
\hline $\mathrm{g}_{\mathrm{s}}$ & 336 hours after application & $y=0,065-6 E-05 x+3 E-08 x^{2}$ & $0,50^{\text {ns }}$ \\
\hline E & 24 hours after application & $y=1,2393-0,0006 x+3 E-07 x^{2}$ & $0,57^{\text {ns }}$ \\
\hline E & 48 hours after application & $\mathrm{y}=0,796-0,0004 x+2 \mathrm{E}-07 \mathrm{x}^{2}$ & $0,89^{*}$ \\
\hline E & 216 hours after application & $y=0,7094-0,0003 x+9 E-08 x^{2}$ & $0,80^{*}$ \\
\hline E & 264 hours after application & $\mathrm{y}=0,5419+0,0001 x-6 \mathrm{E}-08 \mathrm{x}^{2}$ & $0,62^{\text {ns }}$ \\
\hline E & 336 hours after application & $y=0,8238-0,0004 x+1 E-07 x^{2}$ & $0,68^{\mathrm{ns}}$ \\
\hline $\mathrm{Ci} / \mathrm{Ca}$ & 24 hours after application & $y=0,7102-0,0002 x+8 E-08 x^{2}$ & $0,85^{*}$ \\
\hline $\mathrm{Ci} / \mathrm{Ca}$ & 48 hours after application & $y=0,7418+0,0002 x+4 E-08 x^{2}$ & $0,86^{*}$ \\
\hline $\mathrm{Ci} / \mathrm{Ca}$ & 216 hours after application & $y=0,6774+0,0005 x-3 E-07 x^{2}$ & $0,88^{*}$ \\
\hline $\mathrm{Ci} / \mathrm{Ca}$ & 264 hours after application & $\mathrm{y}=0,6774+0,0005 x-3 \mathrm{E}-07 \mathrm{x}^{2}$ & $0,79^{*}$ \\
\hline $\mathrm{Ci} / \mathrm{Ca}$ & 336 hours after application & $\mathrm{y}=0,672+0,0004 x-2 \mathrm{E}-07 \mathrm{x}^{2}$ & $0,96^{*}$ \\
\hline $\mathrm{Fv} / \mathrm{Fm}$ & 24 hours after application & $y=0,7028-0,0001 x+8 E-08 x^{2}$ & $0,84^{*}$ \\
\hline $\mathrm{Fv} / \mathrm{Fm}$ & 72 hours after application & $y=0,6893-0,0001 x+1 E-08 x^{2}$ & $0,80^{*}$ \\
\hline $\mathrm{Fv} / \mathrm{Fm}$ & 120 hours after application & $y=0,7125-3 E-06 x-7 E-08 x^{2}$ & $0,70^{*}$ \\
\hline $\mathrm{Fv} / \mathrm{Fm}$ & 168 hours after application & $y=0,7398-0,0003 x+2 E-07 x^{2}$ & $0,88^{*}$ \\
\hline $\mathrm{Fv} / \mathrm{Fm}$ & 240 hours after application & $y=0,7343-0,0002 x-1 E-08 x^{2}$ & $0,94^{*}$ \\
\hline $\mathrm{Fv} / \mathrm{Fm}$ & 336 hours after application & $y=0,6586-0,0002 x+1 E-07 x^{2}$ & $0,61^{\mathrm{ns}}$ \\
\hline$\Delta \mathrm{F} / \mathrm{Fm}$ & 24 hours after application & $y=0,3897-0,0003 x+1 E-07 x^{2}$ & $0,93^{*}$ \\
\hline$\Delta \mathrm{F} / \mathrm{Fm}$ & 72 hours after application & $y=0,282-0,0004 x+3 E-07 x^{2}$ & $0,72^{*}$ \\
\hline$\Delta \mathrm{F} / \mathrm{Fm}$ & 120 hours after application & $y=0,215-0,0003 x+2 E-07 x^{2}$ & $0,77^{*}$ \\
\hline$\Delta \mathrm{F} / \mathrm{Fm}$ & 168 hours after application & $y=0,1728-0,0002 x+1 E-07 x^{2}$ & $0,84^{*}$ \\
\hline$\Delta \mathrm{F} / \mathrm{Fm}$ & 240 hours after application & $y=0,1728-0,0002 x+1 E-07 x^{2}$ & $0,84^{*}$ \\
\hline$\Delta \mathrm{F} / \mathrm{Fm}$ & 336 hours after application & $y=0,1693-1 E-04 x-5 E-08 x^{2}$ & $0,62^{\text {ns }}$ \\
\hline ETR & 24 hours after application & $\mathrm{y}=72,63-0,1241 \mathrm{x}+5 \mathrm{E}-05 \mathrm{x}^{2}$ & $0,94^{*}$ \\
\hline ETR & 72 hours after application & $y=112,83-0,2112 x+0,0001 x^{2}$ & $0,82^{*}$ \\
\hline ETR & 120 hours after application & $y=80,338-0,0952 x+5 E-05 x^{2}$ & $0,86^{*}$ \\
\hline ETR & 168 hours after application & $y=75,759-0,0871 x+4 E-05 x^{2}$ & $0,85^{*}$ \\
\hline ETR & 240 hours after application & $y=73,547-0,088 x+4 E-05 x^{2}$ & $0,81^{*}$ \\
\hline ETR & 336 hours after application & $y=75,32-0,0717 x-4 E-05 x^{2}$ & $0,63^{\text {ns }}$ \\
\hline NPQ & 24 hours after application & $y=1,1007+0,0011 x-6 E-07 x^{2}$ & $0,90^{*}$ \\
\hline NPQ & 72 hours after application & $y=1,3663+0,0015 x-9 E-07 x^{2}$ & $0,62^{\text {ns }}$ \\
\hline NPQ & 120 hours after application & $y=1,7087+0,0018 x-1 E-06 x^{2}$ & $0,80^{*}$ \\
\hline NPQ & 168 hours after application & $y=1,8894+0,0006 x-4 E-07 x^{2}$ & $0,64^{\mathrm{ns}}$ \\
\hline NPQ & 240 hours after application & $\mathrm{y}=1,914+0,0002 \mathrm{x}-2 \mathrm{E}-06 \mathrm{x}^{2}$ & $0,61^{\mathrm{ns}}$ \\
\hline NPQ & 336 hours after application & $y=1,4173-0,0014 x+9 E-07 x^{2}$ & $0,87^{*}$ \\
\hline
\end{tabular}

$\left({ }^{*}\right),\left({ }^{\mathrm{ns}}\right)$ Significativo e não significativo respectivamente, $\mathrm{p}<5 \%$
Signicant

(Figure 2A), $b$ (Figure 2B) and chlorophyll $a / b$ ratio (Figure 2C). These changes were more evident from the lowest dose $25 \mathrm{~g}$ i.a ha-1, for chlorophyll a and chlorophyll $b$, when compared to the control. For the chlorophyll $\mathrm{a} / \mathrm{b}$ ratio, the decreases also occurred at the lowest dose, but at the dose of $200 \mathrm{~g}$ i.a ha-1, there was an increase in relation to all other doses. When compared to the control, the last dose $1200 \mathrm{~g}$ i.a ha1 , there was a reduction of $36.5 \%$ and $21.7 \%$ in the levels of chlorophyll $a$, in chlorophyll $b$, respectively.

Revista Árvore 2021;45:e4528 

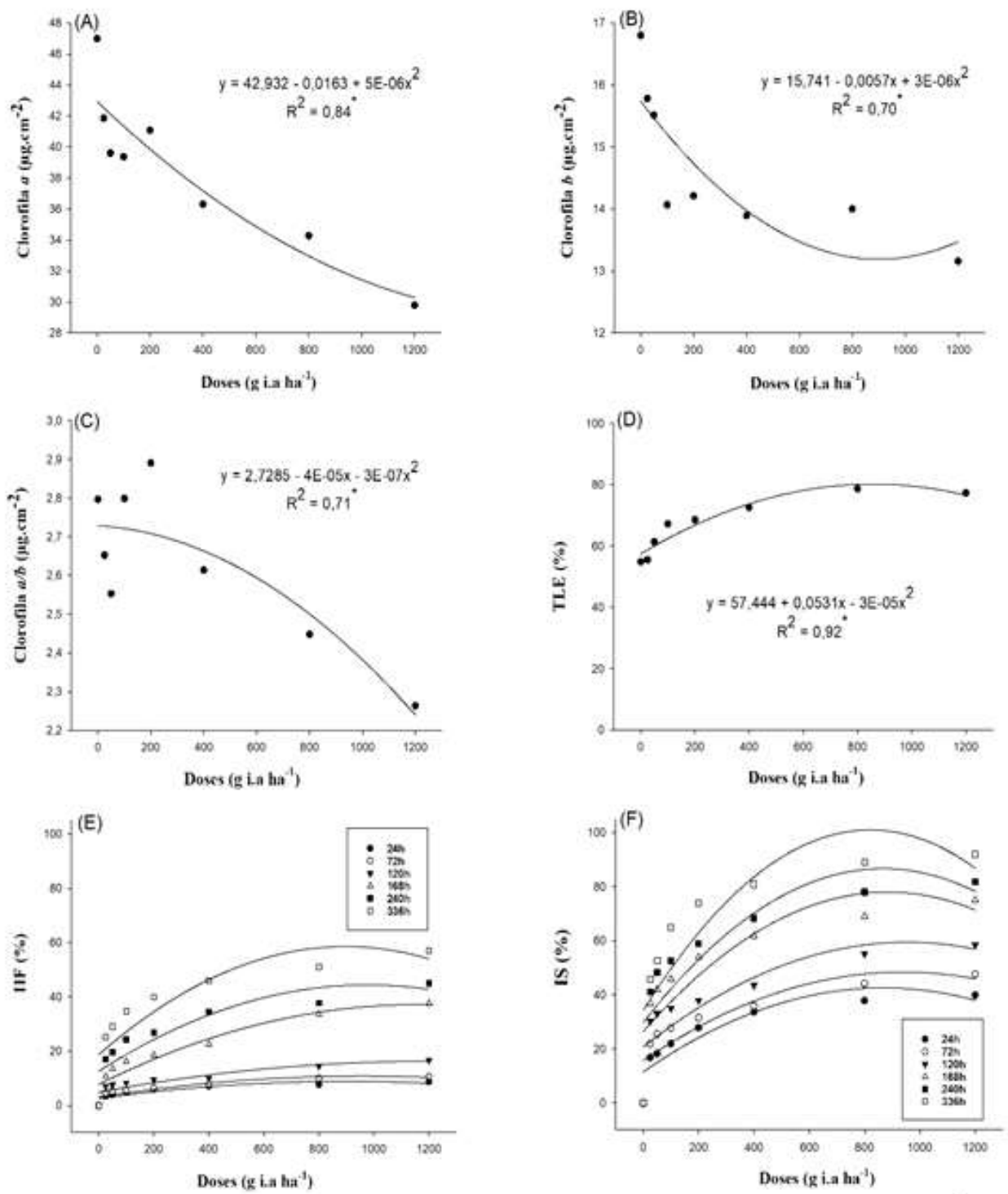

1:F(5) 24 h $y=2,5391+0,0141 x-8 E .06 \times 2 \quad R^{2}=0.80^{\circ}$ ifi(s) $72 \mathrm{~h} y=3,0678+0,0162 x-8 E-06 \times 2 R^{2}=0.83^{4}$ EF(S) $120 \mathrm{~h} y=4.8832+0,019 x-8 E-06 \times 2 \quad R^{2}=0.80^{\circ}$ HF(\%) 1 t6h $y=7,7646 \cdot 0,0508 x \cdot 2 E \cdot 05 \times 2 \quad R^{2}=0.91$ if(S) 240 h $y=12,592+0,0653 x-3 E-05 \times 2 \quad R^{2}=0,81$. HF(\%) $335 \mathrm{~h}$ $y=18.726+0,0398 x-5 E-05 \times 2 \quad R^{2}=0,75$

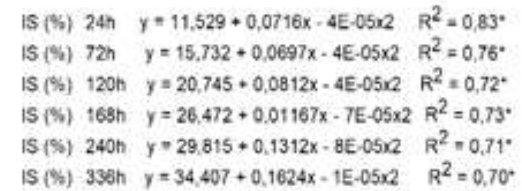

Figure 2 - A-C: Chloroplast pigment content of Bowdichia virgilioides plants subjected to different concentrations of glyphosate. A: chlorophyll $a$; B: chlorophyll $b$; C: chlorophyll $a / b$ ratio; D: Electrolyte release rate in leaf tissues; E: Leaf injury index (IIF) and F: severity index (IS) after 24, 72, 120, 168, 240 and 336 hours after glyphosate application. Below the graphs are the regression equations adjusted for the Leaf Injury Index (LII) and Severity Index (SI). The adjusted regression model was quadratic polynomial. Significance: * $\mathrm{p}<0.05 \%$

Figura 2 -A-C: Conteúdo de pigmentos cloroplastídicos de plantas de Bowdichia virgilioides submetida a diferentes concentrações de glifosato. A: clorofila a; $B$ : clorofila $\boldsymbol{b} ; C$ : razão clorofila a/b; D: Taxa de liberação de eletrólitos em tecidos foliares; E: Índice de injuria foliar (IIF) e F: indice de severidade (IS) após 24, 72, 120, 168, 240 e 336h da aplicação de glifosato. Abaixo dos gráficos encontram-se as equações de regressão ajustadas para Indice de injuria foliar (IIF) e índice de severidade (IS) $O$ modelo de regressão ajustado foi polinomial quadrático. Significância: * $p<0,05 \%$.

Revista Árvore 2021;45:e4528 


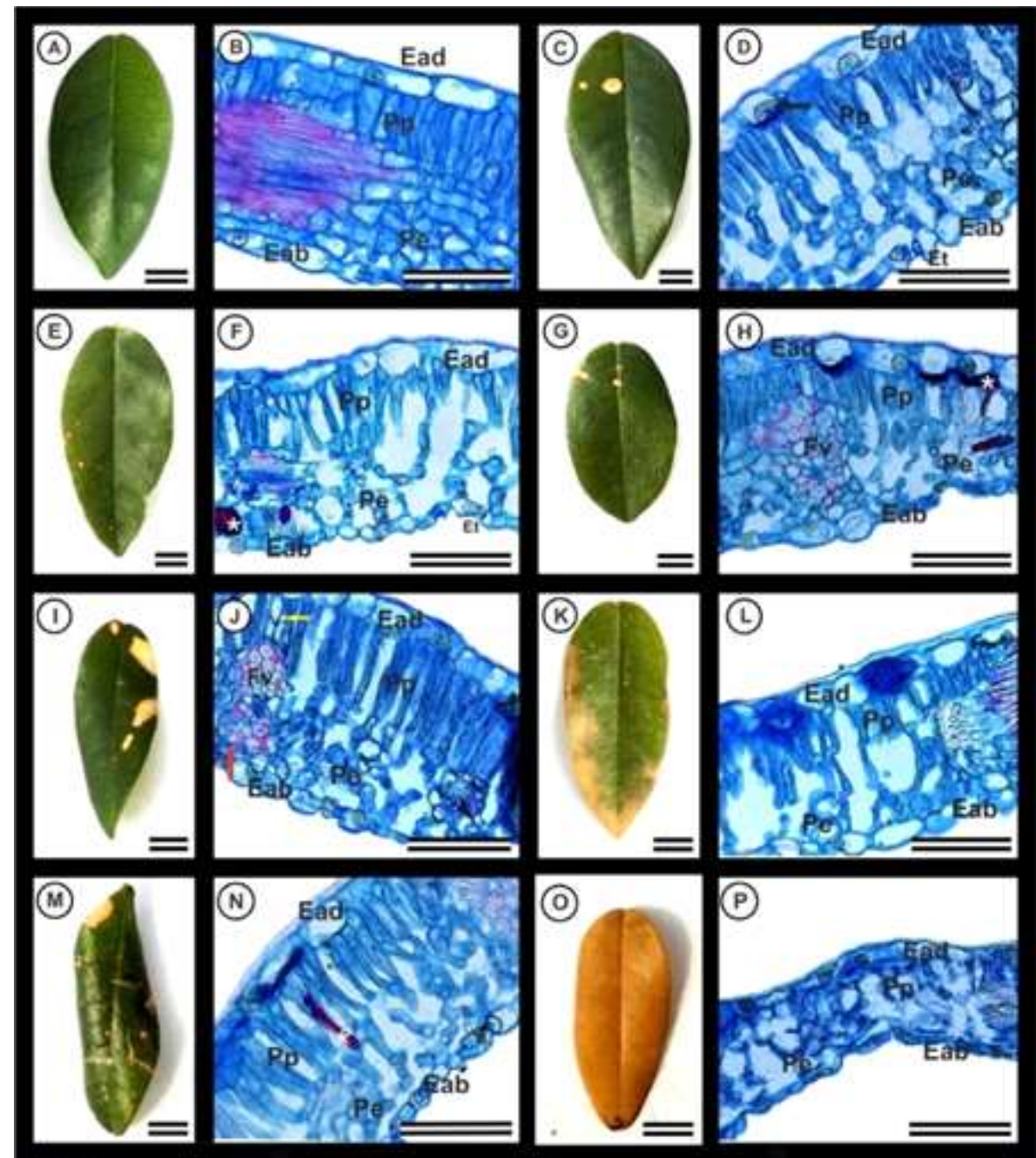

Figure 3 - Leaflet structure of Bowdichia virgilioides Khunt. Control (A and B); and subjected to the action of glyphosate: $25 \mathrm{~g}$ i.a ha ${ }^{-1}$ (C

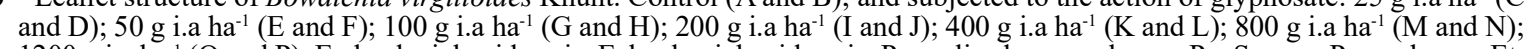
1200 g i.a ha ${ }^{-1}$ (O and P). Ead: adaxial epidermis; Eab: abaxial epidermis; Pp: palisade parenchyma; Pe: Spongy Parenchyma; Et: Stomata; Fv: Vascular bundle; Xi: Xylem; Fl: Phloem; Ba: Sheath; Tc: Trichoma; Prismatic crystals ( $\rightarrow$ red); (A, C, E, G, I, K, $\mathrm{M}$ and $\mathrm{O}) \mathrm{Bar}=1 \mathrm{~cm} ;(\mathrm{B}, \mathrm{D}, \mathrm{F}, \mathrm{H}, \mathrm{J}, \mathrm{L}, \mathrm{N}, \mathrm{P}) \mathrm{Bar}=50 \mu \mathrm{m}$.

Figura 3 - Estrutura do foliolo de Bowdichia virgilioides Khunt. Controle (A e B); e submetida à ação do glifosato: 25 g i.a. ha-1 (C e D);

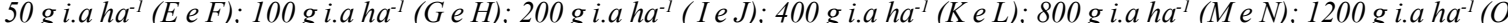
e P). Ead: Epiderme adaxial; Eab: epiderme abaxial; Pp: parênquima paliçádico; Pe: Parênquima esponjoso; Et: Estômato; Fv: Feixe vascular; Xi: Xilema; Fl: Floema; Ba: Bainha; Tc: Tricoma; Cristais priasmáticos ( $\rightarrow$ vermelha); $(A, C, E, G, I, K, M$ e O) Barra $=1 \mathrm{~cm} ;(B, D, F, H, J, L, N, P)$ Barra $=50 \mu \mathrm{m}$

Regarding membrane permeability (Figure 2D), there was an increase in the rate of release of electrolytes from the dose of $50 \mathrm{~g}$ i.a ha-1, with an increase of $11.9 \%$, in relation to the control. When compared to the higher dose, with the control, this increase was $40.9 \%$.

\subsection{Visual assessment of leaf symptoms}

There was a significant increase in LII and SI (Figure 2E and Figure 2F), observed from the lowest dose to the highest dose and in the first evaluation, these damages increased as a result of the time after application. The most evident symptoms were chlorosis, leaf necrosis and, in the highest doses, the curling of some leaves. These effects were enhanced in the evaluation 168 hours after application, when the values for LII were increased by $10.8 \%$ for the lowest applied dose (25 $\mathrm{g}$ i.a ha $\left.\mathrm{h}^{-1}\right)$ and by $37.7 \%$ with the highest dose (1200 g i.a ha-1), for SI the values were $36 \%$ and $75 \%$ respectively. In the last evaluation,

Revista Árvore 2021;45:e4528 
Table 2 - Leaf blade morphometry of Bowdichia virgilioides Kunth., after exposure to different doses of Glyphosate.

Tabela 2 - Morfometria da lâmina foliar de Bowdichia virgilioides Kunth., após exposição a diferentes doses de Glifosato.

\begin{tabular}{|c|c|c|c|c|c|}
\hline Glyphosate & $\operatorname{ADE}(\mu \mathrm{m})^{*}$ & $\mathrm{PP}(\mu \mathrm{m})^{*}$ & $\mathrm{SP}(\mu \mathrm{m})^{*}$ & $\mathrm{ABE}(\mu \mathrm{m})^{\mathrm{ns}}$ & $\overline{\mathrm{LT}(\mu \mathrm{m})^{\mathrm{ns}}}$ \\
\hline$\overline{0}$ & $27,96 \mathrm{a}$ & $67,69 \mathrm{a}$ & $67,09 \mathrm{a}$ & $17,86 \mathrm{a}$ & $171,84 \mathrm{a}$ \\
\hline 25 & $24,22 \mathrm{ab}$ & $57,80 \mathrm{ab}$ & $63,69 \mathrm{ab}$ & $15,64 \mathrm{a}$ & $169,60 \mathrm{a}$ \\
\hline 50 & $25,90 \mathrm{ab}$ & $57,74 \mathrm{ab}$ & $57,63 \mathrm{ab}$ & $14,72 \mathrm{a}$ & $165,28 \mathrm{a}$ \\
\hline 100 & $24,69 \mathrm{ab}$ & $56,56 \mathrm{ab}$ & $57,63 \mathrm{ab}$ & $15,22 \mathrm{a}$ & $186,82 \mathrm{a}$ \\
\hline 200 & $24,43 \mathrm{ab}$ & $58,19 \mathrm{ab}$ & $61,72 \mathrm{ab}$ & $16,63 \mathrm{a}$ & $179,38 \mathrm{a}$ \\
\hline 400 & $24,75 \mathrm{ab}$ & $52,61 \mathrm{ab}$ & $53,41 \mathrm{ab}$ & $15,73 \mathrm{a}$ & $183,66 \mathrm{a}$ \\
\hline 800 & $24,19 \mathrm{ab}$ & $55,53 \mathrm{ab}$ & $53,03 \mathrm{ab}$ & $15,30 \mathrm{a}$ & $180,05 \mathrm{a}$ \\
\hline 1200 & $19,63 \mathrm{~b}$ & $43,73 \mathrm{~b}$ & $42,40 \mathrm{~b}$ & $14,66 \mathrm{a}$ & $144,82 \mathrm{a}$ \\
\hline CV\% & 11,8 & 14,28 & 13,06 & 15,01 & 11,94 \\
\hline
\end{tabular}

$\left({ }^{*}\right),\left({ }^{\text {ns }}\right)$ Significant and non-significant, respectively, at $5 \%$ probability by the $\mathrm{F}$ test. Means followed by the same letter in the column do not differ from each other at 5\% probability by Tukey's test. ADE: adaxial epidermis; PP: Palisade parenchyma; SP: Spongy Parenchyma; ABE: abaxial epidermis; LT: Leaflet thickness.

$\left.\left.{ }^{*}\right),{ }^{\text {ns }}\right)$ Significativo e não significativo respectivamente, a $5 \%$ de probabilidade pelo teste $\mathrm{F}$. Médias seguidas pela mesma letra na coluna não diferem entre si a 5\% de probabilidade pelo Teste de Tukey. Ead: Epiderme adaxial; Pp: Parênquima paliçádico; Pe: Parênquima esponjoso; Eab: Epiderme abaxial; Ef: Espessura do folíolo.

there was an increase of $56 \%$ in LII and $92 \%$ in SI with the highest dose.

\subsection{Anatomical analyzes}

The alterations observed in the leaves $B$. virgilioides were: disorganization of the mesophyll, with cells of different formats from the dose of $50 \mathrm{~g}$ i.a ha ${ }^{-1}$ (Figure 3F) and with the doses 400, 800 and $1200 \mathrm{~g}^{\text {i.a ha }}{ }^{-1}$ (Figures 3L, 3N and 3P), the tissues were totally destroyed with a twisted aspect; changes in the format of the chloroplasts mainly from the dose of $400 \mathrm{~g}$ i.a ha-1; dark blue contents were detected inside the vacuoles of the cells of the epidermis and parenchyma, with the dose of $800 \mathrm{~g}$ i.a ha ${ }^{-1}$; and accumulation of contents with reddish color in the palisade parenchyma, mainly at the dose of $200 \mathrm{~g}$ i.a $\mathrm{ha}^{-1}$. After histochemical tests, the reaction to ferric chloride was observed only in the treatments with a blackish color in the palisade parenchyma, indicating the presence of general phenolic compounds. Hydrochloric vanillin did not indicate a positive reaction for tannins.

The micromorphometric analysis revealed that the plants exposed to glyphosate showed significant reductions in the thickness of the adaxial epidermis (Ead), palisade parenchyma (Pp) and spongy parenchyma $(\mathrm{Sp})$. The most significant reductions were seen in the highest applied dose (1200 g i.a ha $\left.{ }^{-1}\right)$. The parameters of thickness of the epidermis of the abaxial face (Eab) and thickness of the leaflet (Ef) did not show significant reductions (Table 2). Despite major changes in tissue structures, the reduction in the thickness of the leaflet was only $16 \%$ compared to the control (Table 2).

\section{DISCUSSION}

Exposure to glyphosate interfered with the physiological characteristics of $B$. virgilioides plants, changing all parameters of gas exchange evaluated, according to the increase in applied doses. The impacts caused by photosynthetic parameters are a consequence of the decrease in EPSPS and, consequently, by the accumulation of shikimic acid in plant tissues, which affects development (Gomes et al., 2017; Freitas-Silva et al., 2020). The The decrease in the values of $A, \mathrm{~g}_{\mathrm{s}}$ and $E$, as observed in this study, may be partially related to the mode of action of glyphosate in stomatal cells, since the guard cells are directly affected by this herbicide, which can cause stomatal closure (Yanniccari et al., 2012), reducing the flow of $\mathrm{CO}_{2}$ available for photosynthesis, i.e. the lower the values of stomatal conductance the greater the resistance to $\mathrm{CO}_{2}$ entry, causing significant effects on photosynthetic and transpiration rates, reducing carboxylative efficiency (Machado et al., 2010). Similar responses were observed by Batista et al. (2018), when analyzing the effects caused by glyphosate in the Pouteria torta species, where it was observed that these parameters decreased in response to the increase in glyphosate doses and the evaluation times, suggesting that the decrease in the photosynthetic process occurred, at least in part through stomatal limitations.

However, due to the decrease in stomatal conductance, it was expected that there would be a reduction in the $\mathrm{C}_{i} / \mathrm{C}_{a}$ ratio, since the closure of the stomata limits the entry of $\mathrm{CO}_{2}$, causing the consumption of $\mathrm{CO}_{2}$ present in the mesophyll $\left(\mathrm{C}_{\mathrm{i}}\right)$ naturally, thus decreasing the ratio $\left(\mathrm{C}_{\mathrm{i}} / \mathrm{C}_{\mathrm{a}}\right)$ (Santos et 
al., 2020). However, there was a significant increase in $\left(\mathrm{C}_{\mathrm{i}} / \mathrm{C}_{\mathrm{a}}\right)$, indicating the accumulation of $\mathrm{CO}_{2}$ in the substomatal cavity, a fact that shows that the effect was not caused only by stomatal limitations. According to Fernandes et al. (2015), considering that there is a constant concentration of external $\mathrm{CO}_{2}\left(\mathrm{C}_{\mathrm{a}}\right)$, the increase in the ratio $\left(\mathrm{C}_{\mathrm{i}} / \mathrm{C}^{\mathrm{a}}\right)$ occurs due to variations in the internal concentration $\left(\mathrm{C}_{\mathrm{i}}\right)$. If there are increases in $\mathrm{C}_{\mathrm{i}}$, it means that the $\mathrm{CO}_{2}$ which is reaching the mesophyll cells is not being fixed in the carboxylation phase of ribulose 1,5 bisphosphate carboxylaseoxygenase (Rubisco), probably due to lesions in the chloroplasts, reducing the photosynthetic rate. FreitasSilva et al. (2020), when studying the responses of Handroanthus chrysotrichus to glyphosate, indicated that the increases in $\left(\mathrm{C}_{\mathrm{i}} / \mathrm{C}_{\mathrm{a}}\right)$ may be due to biochemical limitations. These limitations are related to factors such as the limitation of the synthesis of the rubisco enzyme, and decreased chlorophyll synthesis promoted by the herbicide (Yanniccari et al., 2012).

There were decreases in the Fv/Fm ratio, observed since the first evaluation, being more accentuated at higher doses, indicating that the applied doses damaged the photosynthetic apparatus. Values of this parameter in plants under non-stressed conditions range from 0.75 to 0.85 , while decreases in these values are indicative of photoinhibition (Maxwell and Johnson, 2000; Silva et al., 2016). The reduction in the values referring to the $\Delta \mathrm{F} / \mathrm{Fm}^{\prime}$ ratio, as well as the ETR and the increase in the NPQ, indicate that $B$. virgilioides suffered severe damage in the FSII. As a result, significant reductions were also found in the chlorophyll $a$, chlorophyll $b$ and chlorophyll $a / b$ ratio contents. Silva et al. (2016), also found reductions in chlorophyll content in the species Caryocar brasiliense, as did Batista et al. (2018), in Pouteria torta plants, and state that increased NPQ ameliorated the damage to the photosynthetic apparatus triggered by glyphosate in Pouteria torta, supported by reduced $\mathrm{Fv} / \mathrm{Fm}$, which indicates that damage to the structure of the thylakoids may have occurred, possibly due to photooxidative stress.

Changes in the content of chloroplast pigments caused increases in the electrolyte release rate (ERR), even at the lowest doses, indicating that glyphosate promoted membrane damage. It is believed that this is due to the fact that this herbicide stimulates the synthesis of the hormone ethylene, which, in turn, stimulates the synthesis of phospholipid degradation enzymes, decreasing the stability of cell membranes (Yamada and Castro, 2007). Another explanation for this effect, is related to the increased formation of reactive oxygen species (ROS), because alterations in metabolic pathways caused by herbicides, are able to increase oxidative stress (Sharma et al., 2012), causing electrolyte leakage. Cruz et al. (2021), found that the overproduction of ROSs promoted lipid peroxidation in cell membranes of E. uniflora leaves exposed to glyphosate, which resulted in extravasation of cell contents, decreased photosynthetic rate, anatomical changes and visual symptoms of phytotoxicity damage also observed in this study.

As a consequence of the physiological damage evidenced, the visual symptoms of intoxication of the plants exposed to glyphosate, were characterized by the presence of chlorosis and necrosis and the curling of some leaves. The phytotoxicity and severity indices were more expressive after 168 hours of application, and in the two highest doses (800 and $1200 \mathrm{~g}$ i.a ha$\left.{ }^{1}\right)$. Symptoms similar to these were also observed in other forest species subjected to glyphosate, such as Caryocar brasiliense (Silva et al., 2016), Handroanthus chrysotrichus (Freitas-Silva et al., 2020), and Eugenia uniflora L. (Cruz et al., 2021). Visual symptoms such as chlorosis and necrosis observed in $B$. virgilioides leaves may have occurred due to the overproduction of ROS, associated with anatomical changes such as protoplast retraction and cell collapse. These symptoms are common due to the initial interaction between the herbicide droplets and the plant's leaf surface (Lima et al., 2017; FreitasSilva et al., 2020; Cruz et al., 2021).

In view of this, there was also damage to the anatomy of the leaf of $B$. virgilioides, there were changes in the organization of the mesophyll and in the format of the cells, being more expressive at higher doses, confirming that the effects are directly linked to the increase in doses. There was a significant reduction in thickness, in the adaxial epidermis and in the palisade and spongy parenchyma, and in higher doses the tissues were collapsed, the palisade and spongy parenchyma disorganized, with a twisted aspect. Santos et al. (2020), found similar symptoms in the Cenostigma macrophyllum species, mainly in the highest dose of glyphosate applied. For these authors, the reduction of observed leaf tissues may

Revista Árvore 2021;45:e4528 
have contributed to the deficiency of $\mathrm{CO}_{2}$ diffusion in the mesophyll, a fact also observed in the present study.

The histochemical test confirmed the presence of phenolic compounds in $B$. virgilioides, and that the presence of these compounds was due to the application of the herbicide, as they were not found in the control treatment. It was found that these phenolic compounds are not tannins, as the hydrochloric vanillin did not indicate a positive reaction for them, requiring further studies with other reagents to identify which metabolic group these compounds belong to. According to Shaner et al. (2012), glyphosate probably caused these changes by acting on the shikimic acid route, which is responsible for the biosynthesis of aromatic amino acids such as tyrosine, tryptophan and phenylalanine, precursors of nitrogenous side products, which participate in the production of phenolic compounds.

\section{CONCLUSIONS}

The results indicated that glyphosate is phytotoxic to $B$. virgilioides, at the doses studied, as it promoted several physiological, anatomical and visual changes, which were more expressive with increasing doses. The changes observed in this study are possibly a consequence of the decrease in EPSPs, stomatal limitations, biochemical restrictions and overproduction of ROS, thus proving the sensitivity of $B$. virgilioides to glyphosate. Therefore, the observed responses may serve as a diagnostic tool for the effects of glyphosate on this species in vegetation fragments affected by the drifting of this herbicide, as its indiscriminate use is a risk to the Cerrado's biodiversity.

\section{AUTHOR CONTRIBUTIONS}

Ana Paula Augusta de Oliveira: Author of the work. Experiment execution, data analysis, interpretation of experimental data. Discussion and writing of the results in the article. Article Submission.

Ailton José Crispim-Filho: Collaboration in the experiment and statistical analysis.

Vanessa Ribeiro de Souza Santos: Assistance in the experiment and in reviewing the writing of the article.
Alan Carlos Costa: Co-orientation of the work. Assistance in the interpretation of physiological data analysis.

Kellen Lagares Ferreira Silva: Guidance and coordination of the work. Data design and analysis. Active participation in writing results and discussion. Final review. Article Submission.

\section{ACKNOWLEDGMENTS}

The Federal University of Tocantins, the Instituto Federal Goiano-Campus Rio Verde for the partnership and CNPq for the scholarship granted.

\section{REFERENCES}

Aguiar TV, Santanna-Santos BF, Azevedo AA, Ferreira RS. ANATI QUANTI: software de análises quantitativas para estudos em anatomia vegetal. Planta Daninha. 2007;25(4):649-659. doi: 10.1590/ S0100-83582007000400001

Batista PF, Costa AC, Megguer CA, Lima JS, Silva FB, Guimarães DS, et al. Pouteria torta: a native species of the Brazilian Cerrado as a bioindicator of glyphosate action. Brazilian Journal of Biology. 2018;78(2):296-305. doi: 10.1590/1519-6984.07416

Benbrook CM. Trends in glyphosate herbicide use in the United States and globally. Environmental Sciences Europe. 2016;28(3):1-15. doi: 10.1186/ s12302-016-0070-0

Belchior DCV, de Souza Saraiva A, López AMC, Scheidt GN. Impactos de agrotóxicos sobre o meio ambiente e a saúde humana. Cadernos de Ciência \& Tecnologia. 2014;34(1):135-151.

Bilger W, Schreiber U, Bock M. Determination of the quantum efficiency of photosystem II and of non-photochemical quenching of chlorophyll fluorescence in the field. Oecologia. 1995;102(4):425-432. doi: 10.1007/BF00341354

Brancalion PHS, Isernhagen I, Machado RP, Christoffoleti PJ, Rodrigues RR. Seletividade dos herbicidas setoxidim, isoxaflutol e bentazon a espécies arbóreas nativas. Pesquisa Agropecuária Brasileira. 2009;44(3):251-257. doi: 10.1590/S0100204X2009000300005

Coêlho CB, Lira Paulo FV, Viana BL. Dormancy 
overcoming in Bowdichia virgilioides Kunth Seeds. Revista Ciência Agrícola. 2019;17(2):73-79. doi: 10.28998/rca.v17i2.5180

Cruz CES, de Freitas-Silva L, Ribeiro C, Silva LC da. Physiological and morphoanatomical effects of glyphosate in Eugenia uniflora, a Brazilian plant species native to the Atlantic Forest biome. Environmental Science and Pollution Research. 2021;28(17):21334-21346. doi: 10.1007/s11356-020$12003-4$

El-Khatib AA. The response of some common Egyptian plants to ozone and their use as biomonitors. Environmental Pollution. 2003;124(3):419-428. doi: 10.1016/S02697491(03)00045-9

Fernandes ET, Cairo PAR, Novaes AB. Physiological responses of eucalyptus clones grown in a greenhouse under water deficit. Ciência Rural. 2015;45(1):29-34. doi: 10.1590/0103$8478 \mathrm{cr} 20120152$

Freitas-Silva L, Araújo TO, Nunes-Nesi A, Ribeiro C, Costa AC, Silva LC. Evaluation of morphological and metabolic responses to glyphosate exposure in two neotropical plant species. Ecological Indicators. 2020;113:106246. doi: 10.1016/j. ecolind.2020.106246

Gerlach, D. Botanische Mikrotechnik: Eine Einführung. Sttutgart: Georg Thieme Verlag; 1984.

Gomes CS. Impactos da expansão do agronegócio brasileiro na conservação dos recursos naturais. Cadernos do Leste. 2019;19(19). [cited 2021 March 5]. Avaible from: https://periodicos.ufmg.br/index. php/caderleste/article/view/13160/10396

Gomes MP, Le Manac'h SG, Hénault-Ethier L, Labrecque M, Lucotte M, Juneau P. Glyphosatedependent inhibition of photosynthesis in willow. Frontiers in plant science. 2017;8:207. doi: 10.3389/ fpls.2017.00207

Haupt, A. W. A gelatin fixative for paraffin sections. Stain Technology. 1930;5(3):97-98. doi: $10.3109 / 10520293009115555$

Hoagland DR, Arnon DI. The water-culture method for growing plants without soil. California Agricultural Experiment Station. 1950;347:1-32.
Karnovsky MJ. A formaldehyde glutaraldehyde fixative of high osmolality for use in eléctron microscopy. The Journal of Cell Biology. 1965;27(2):137-139.

Kirkwood RC, Mckay I. Accumulation and elimination of herbicides in selected crop and weed species. Pesticid Science. 1994;42(3):241-249.

Lima DA, Müller C, Costa AC, Batista PF, Dalvi VC, Domingos M. Morphoanatomical and physiological changes in Bauhinia variegata L. as indicators of herbicide diuron action. Ecotoxicol and environment safety. 2017;141:242-250. doi: 10.1016/j.ecoenv.2017.03.038

Lorenzi H. Árvores Brasileiras: Manual de Identificação de Identificação e Cultivo de Plantas Arbóreas Nativas do Brasil. Nova Odessa: Instituto Plantarum; 2008. v.3. ISBN 978-8586714504

Machado AFL, Ferreira LR, Santos LDT, Ferreira FA, Viana RG, Machado MS, et al. Eficiência fotossintética e uso da água em plantas de eucalipto pulverizadas com glyphosate. Planta Daninha. 2010;28(2):319-327. doi: 10.1590/S010083582010000200011

Maxwell K, Johnson GN. Chlorophyll fluorescence-a practical guide. Journal of Experimental Botany. 2000;51(345):659-668. doi: 10.1093/ jexbot/51.345.659

Moura LMF, Costa AC, Müller C, Silva Filho RO, Almeida GM, Vital RG, et al. Drought tolerance in potential oilseed plants for biofuel production. Australian Journal of Crop Science. 2018;12(2): 289298. doi: 10.21475/ajcs.18.12.02.pne836

Novak K, Skelly JM, Shaub M, Kräuchi N, Christian H, Landolt W, Bleuler P. Ozone air pollution and foliar injury development on native plants of Switzerland. Environmental Pollution. 2003;125(1):41-52. doi: 10.1016/S02697491(03)00085-X

Pelaez V, Terra FHB, Silva LR. A regulamentação dos agrotóxicos no Brasil: entre o poder de mercado e a defesa da saúde e do meio ambiente. Revista de Economia. 2010;36(1):27-48. doi: 10.5380/ re.v36i1.20523

Pimentel C, Sarr B, Diouf O, Abboud ACS, Roy-

Revista Árvore 2021;45:e4528 
Macauley H. Tolerância protoplasmática foliar à seca, em dois genótipos de caupi cultivados em campo. Revista Universidade Rural, Série Ciências da Vida. 2002;22(1):7-14

Rascher U, Liebig M, Lüttge U. Evaluation of instant light-response curves of chlorophyll fluorescence parameters obtained with a portable chlorophyll fluorometer on site in the field. Plant, Cell \& Environment. 2000;23(12):1397-1405. doi: 10.1046/j.1365-3040.2000.00650.x

Santana CAM, Campos SK, Marra R, Aragão AA. Cerrado: pilar da agricultura brasileira. In: Bolfe EL, Sano EE, Campos SK, editors. Dinâmica agrícola no cerrado: análises e projeções. Brasília: Embrapa; 2020 [cited 2021 March 5]. Avaible from: https://ainfo.cnptia.embrapa.br/digital/bitstream/ item/212381/1/LV-DINAMICA-AGRICOLACERRADO-2020.pdf. ISBN 978-85-7035-951-3.

Santos VRS, Crispim Filho AJ, Santana MM, Costa AA, Silva KLF. Análises fisiológicas e morfoanatômicas de Cenostigma macrophyllum TUL. (Fabaceae) submetida a diferentes concentrações de glifosato. Revista Ibero-Americana de Ciências Ambientais. 2020;11(5):159-173. doi: 10.6008/CBPC2179-6858.2020.005.0017

Shaner DL, Lindenmeyer RB, Ostlie MH. What have the mechanisms of resistance to glifosato taught us? Pest Management Science. 2012;68(1):3-9. doi: $10.1002 /$ ps.2261

Sharma P, Jha AB, Dubey RS, Pessarakli M. Reactive oxygen species, oxidative damage, and antioxidative defense mechanism in plants under stressful conditions. Journal of Botany. 2012;2012:1-
26. doi: $10.1155 / 2012 / 217037$

Silva LQ, Araújo ACF, Almeida GM, Filho AJC, Costa AC, Jakelaitis A. Modificações fisiológicas em folhas de pequi (Caryocar brasiliense) causadas pela aplicação de glyphosate. Revista Brasileira de Herbicidas. 2016;15(2):184-194. doi: 10.7824/rbh. v15i2.472

Van Kooten O, Snel JFH. The use of chlorophyll fluorescence nomenclature in plant stress physiology. Photosynthesis Research. 1990;25:147-150. doi: 10.1007/BF00033156

Vasquez-Tello A, Zuily-Fodil Y, Thi ATP, Silva JBV. Electrolyte and Pi leakages and soluble sugar content as physiological tests for screening resistance to water stress in Phaseolus and Vigna species. Jounal Experimental Botany. 1990;41(7):827-832. doi: $10.1093 / \mathrm{jxb} / 41.7 .827$

Wellburn AR. The spectral determination of chlorophylls a and b, as well as total carotenoids, using various solvents with spectrophotometers of different resolution. Journal of Plant Physiology. 1994;144(3):307-313. doi: 10.1016/S0176$1617(11) 81192-2$

Yamada T, Castro PRC. Efeitos do glifosato nas plantas: implicações fisiológicas e agronômicas. International plant nutrition institute. 2007;119(1):1-32.

Yanniccari M, Tambussi E, Istilart C, Castro AM. Glyphosate effects on gas exchange and chlorophyll fluorescence responses of two Lolium perenne L. biotypes with differential herbicide sensitivity. Plant Physiology. Biochemistry. 2012;57:210-217. doi: 10.1016/j.plaphy.2012.05.027 